DOE/NASA/16310-20

NASA TM-106370

\title{
Effects of Processing and Prolonged High Temperature Exposure on the Microstructure of $\mathrm{Nb}-1 \mathrm{Zr}-\mathrm{C}$ Sheet
}

Mehmet Uz

Lafayette College

and

R.H. Titran

National Aeronautics and Space Administration Lewis Research Center

Work performed for

\section{U.S. DEPARTMENT OF ENERGY}

Nuclear Energy

Reactor Systems Development and Technology

Prepared for

MRS 1993 Fall Meeting

sponsored by the Materials Research Society

Boston, Massachusetts, November 29-December 3, 1993 


\title{
Effects of Processing and Prolonged HighTemperature Exposure on the Microstructure of $\mathrm{Nb}-1 \mathrm{Zr}-\mathrm{C}$ Sheet
}

\author{
Mehmet Uz \\ Lafayette College \\ and \\ R.H. Titran \\ National Aeronautics and Space Administration \\ Lewis Research Center \\ Cleveland, Ohio 44135
}

Work performed for

U.S. DEPARTMENT OF ENERGY

Nuclear Energy

Reactor Systems Development and Technology

Washington, D.C. 20545

Under Interagency Agreement DE-AI03-86SF16310

\section{Prepared for}

MRS 1993 Fall Meeting

sponsored by the Materials Research Society

Boston, Massachusetts, November 29-December 3, 1993 
Mehmet $U z^{*}$ and R. H. Titran ${ }^{* *}$

** Chemical Engineering Department, Lafayette College, Easton, PA 18042

${ }^{\star *}$ NASA Lewis Research Center, MS 49-1, Cleveland, OH 44135

\section{ABSTRACT}

High temperature stability of the microstructure of $\mathrm{Nb}-1 \mathrm{Zr}$ sheet containing 0.1 and 0.06 wt.\% $\mathrm{C}$ was studied as affected by processing and prolonged $1350-\mathrm{K}$ exposure with and without applied stress. Sheets were fabricated by cold rolling bars that were single-, double- or triple-extruded at $1900 \mathrm{~K}$. Creep samples were double-annealed ( $1 \mathrm{~h}$ - $1755 \mathrm{~K}+2 \mathrm{~h}$ - $1475 \mathrm{~K}$ ) prior to testing at $1350 \mathrm{~K}$ for $10,000-34,500 \mathrm{~h}$. The microstructures of the as-cast, extruded, rolled, DA and crept samples were characterized using various metallographic and analytical methods. The precipitates were rather coarse $\mathrm{Nb}_{2} \mathrm{C}$ initially, but transformed to finer $(\leq \mathrm{l} \mu \mathrm{m})$ carbides of $(\mathrm{Zr}, \mathrm{Nb}) \mathrm{C}$ with each subsequent high temperature process. The grain size, and the relative amount and morphology of $(\mathrm{Zr}, \mathrm{Nb}) \mathrm{C}$ were found to be affected by the number of extrusions and to some extent by $C$-content. However, the microstructures of all the crept samples were similar with $(\mathrm{Zr}, \mathrm{Nb}) \mathrm{C}$ distributed throughout the matrix indicating that prolonged exposure to $1350 \mathrm{~K}$ gave rise to complete transformation of $\mathrm{Nb}_{2} \mathrm{C}$ to $(\mathrm{Zr}, \mathrm{Nb}) \mathrm{C}$ regardless of the processing history. These and other observations are presented with the emphasis on the correlation between processing, microstructure and creep properties.

\section{INTRODUCTION AND BACKGROUND}

Advanced power systems with a nuclear reactor as the primary heat source are being developed to provide electricity for future space missions. One of the critical concerns is the selection of the proper materials to meet the rather stringent design requirements of the reactor system. These include a full-power (100 kW) operating 7 ife of 7 years at $1350-1450 \mathrm{~K}$ and $5-25 \mathrm{MPa}$ in a 7 iquid alkali metal environment with total creep strain of less than $2 \%^{1,2}$. Nb-Zr alloys with and without $C$ were selected over other refractory metal alloys primarily because of their resistance to liquid alkali metal corrosion, ease of fabrication and relatively low densities. In particular, Nb-1Zr (al] compositions in wt.\%) was chosen for ground demonstration of the power system ${ }^{3}$ and $\mathrm{Nb}-1 \mathrm{Zr}-0.1 \mathrm{C}_{2}$ an alloy developed in $1960 \mathrm{~s}^{4}$, was suggested to provide additional design margins $\mathrm{s}^{5}$. Reactor test loops with components made from both alloys have been tested successfully in liquid lithium for up to 3200 hours $^{6}$. However, recent work ${ }^{7-10}$ showed that the creep resistance of the precipitate-hardened $\mathrm{Nb}-1 \mathrm{Zr}-\mathrm{C}$ alloys is superior to that of the solid solution-strengthened $\mathrm{Nb}-1 \mathrm{Zr}$. Based upon weight limits, it was also clear that a Nb-1Zr-C alloy must be used in the parts of the power system where the stresses are expected to approach or exceed $10 \mathrm{MPa}$ at $1350 \mathrm{~K}$ when a service life of 7 years or more is required ${ }^{10}$.

The strength and creep resistance of $\mathrm{Nb}-\mathrm{Zr}-\mathrm{C}$ alloys is due to the carbides of $\mathrm{Nb}$ and/or $\mathrm{Zr}$; therefore, it is important to have a complete understanding of their precipitation sequence, morphology and high temperature stability. A number of studies have been reported on microstructural characterization of the $\mathrm{Nb}-\mathrm{Zr}-\mathrm{C}$ alloys ${ }^{11-23}$, but only a few investigated the effects of processing and long-term exposure to elevated temperatures ${ }^{10,22,23}$. This paper deals with the characterization and long-term stability of the microstructure of $\mathrm{Nb}-1 \mathrm{Zr}$ sheets containing 0.06 and $0.1 \mathrm{C}$ as affected by processing and carbon content with the emphasis on precipitate composition and morphology. 


\section{EXPERIMENTAL}

Samples were taken from the materials before and after each process, and the condition of each as examined in this study is listed in Table I. Uniaxial creep tests were conducted on 1-mm thick sheets fabricated from vacuum arc-melted (VAM) ingots by a combination of hot extrusion and cold rolling operations as indicated. Two $\mathrm{Nb}-1 \mathrm{Zr}-0.06 \mathrm{C}$ samples were creep tested, one in double-annealed (DA) and the other in double-annealed and aged (DA/AGE) condition. A sample from each of the three $\mathrm{Nb}-1 \mathrm{Zr}-0.1 \mathrm{C}$ sheets was also creep tested after the doubleanneal heat treatment. All the creep tests were carried out in vacuum $\left(10^{-6} \mathrm{~Pa}\right.$ or better pressure) at $1350 \mathrm{~K}$ for times ranging from about $10,000 \mathrm{~h}$ to $34,500 \mathrm{~h}$. The ends (E) of each of the crept samples were assumed to be heat treated without applied stress, because the regions beyond the grips of the uniaxial creep samples underwent no measurable deformation. This allowed the assessment of the effect of stress on the microstructure during high temperature exposure.

The as-received samples were chemically analyzed to verify initial composition. Additionally, all the heat-treated and crept samples were analyzed to monitor the loss or pick up of interstitial impurities $(0, N, C)$.

Table I. Processing history and condition of each sample from sheets of $\mathrm{Nb}$ $1 \mathrm{Zr}-0.06 \mathrm{C}$ (LC-samples) and Nb-1Zr-0.1C (064-samples).

\begin{tabular}{|c|c|c|}
\hline SAMPLE & $\begin{array}{l}\text { NUMBER OF } \\
\text { EXTRUSIONS }^{(2)}\end{array}$ & HEAT TREATMENT/CONDITION \\
\hline LC & 1 & AS COLD ROLLED \\
\hline LC-DA & 1 & $\mathrm{DA}^{(\mathrm{d})}$ \\
\hline LC-DA10(E) $)^{(\mathbf{b})}$ & 1 & $\mathrm{DA}+34,500 \mathrm{~h} @ 1350 \mathrm{~K}$ \\
\hline LC-DA10(M) ${ }^{(\mathbf{c})}$ & 1 & $\mathrm{DA}+34,500 \mathrm{~h} @ 1350 \mathrm{~K}$ and $10 \mathrm{MPa}$ \\
\hline LC-DA/AGE & 1 & $\mathrm{DA}+\mathrm{AGE}^{(e)}$ \\
\hline LC-DA/AGE10(E) & 1 & $\mathrm{DA}+\mathrm{AGE}+32,500 \mathrm{~h} @ 1350 \mathrm{~K}$ \\
\hline LC-DA/AGE10(M) & 1 & $\mathrm{DA}+\mathrm{AGE}+32,500 \mathrm{~h} @ 1350 \mathrm{~K}$ and $10 \mathrm{MPa}$ \\
\hline 064-INGOT & & VACUUM ARC-MELTED INGOT \\
\hline 064A & 1 & AS COLD ROLLED (96\%) \\
\hline 064A-DA & 1 & DA \\
\hline 064A-DA34(E) & 1 & $\mathrm{DA}+18780 \mathrm{~h} @ 1350 \mathrm{~K}$ \\
\hline 064A-DA34(M) & 1 & $\mathrm{DA}+18780 \mathrm{~h} @ 1350 \mathrm{~K}$ and $34.5 \mathrm{MPa}$ \\
\hline 064B & 2 & AS COLD ROLLED (88\%) \\
\hline 064B-DA & 2 & DA \\
\hline 064B-DA34(E) & 2 & $\mathrm{DA}+15460 \mathrm{~h} @ 1350 \mathrm{~K}$ \\
\hline 064B-DA34(M) & 2 & $\mathrm{DA}+15460 \mathrm{~h} @ 1350 \mathrm{~K}$ and $34.5 \mathrm{MPa}$ \\
\hline 064C & 3 & AS COLD ROLLED (60\%) \\
\hline 064C-DA & 3 & $\mathrm{DA}$ \\
\hline 064C-DA34(E) & 3 & $\mathrm{DA}+9950 \mathrm{~h} @ 1350 \mathrm{~K}$ \\
\hline $064 \mathrm{C}-\mathrm{DA} 34(\mathrm{M})$ & 3 & $\mathrm{DA}+9950 \mathrm{~h} @ 1350 \mathrm{~K}$ and $34.5 \mathrm{MPa}$ \\
\hline
\end{tabular}

(a) Number of hot $(1900 \mathrm{~K})$ extrusions prior to cold rolling of the sheet bars.

(b) (E): Low-stress end portions of crept sample.

(c) (M): Stressed gage section of crept sample. Total strain was $<0.3 \%$ in each.

(d) DA: Double-anneal, 1h @ 1755 K + 2h @ $1475 \mathrm{~K}$, furnace-cooled after each step.

(e) AGE: Heat treatment of 1000 h @ $1350 \mathrm{~K}$ followed by furnace cooling. 
The sheet samples were examined in the as-polished condition by light microscopy and scanning electron microscopy (SEM) for precipitate morphology and distribution. The polished specimens were also etched by a solution of $30 \mathrm{ml}$ lactic-15 m7 nitric-5 ml hydrofluoric acids and then examined by 1ight microscopy for grain size. A 7 ineal intercept method ${ }^{24}$ was used to determine the grain size. Phase extraction was performed on each specimen listed in Table I using a solution of $900 \mathrm{ml}$ methanol-100 $\mathrm{ml}$ bromine-10 g tartaric acid with platinum as the catalyst. The residue obtained from each was analyzed by (1) $x$-ray spectroscopy for precipitate identification and (2) an inductively-coupled plasma (ICP) method for $\mathrm{Nb}$ and $\mathrm{Zr}$ contents. The double-annealed samples from the $\mathrm{Nb}-1 \mathrm{Zr}$ $0.1 \mathrm{C}$ sheets were also examined by transmission electron microscopy (TEM) to verify the results from X-ray analys is of the residue. Energy-dispersive X-ray spectroscopy (XEDS) using SEM was also performed on various residue samples to verify the trends observed from the ICP results.

\section{RESULTS AND DISCUSSION}

\section{Chemical Analysis and Metallography}

The chemical composition and grain size of the samples are given in Table II. These together with the microstructural observations are discussed below.

Table II. Chemical analysis and grain size for $\mathrm{Nb}-1 \mathrm{Zr}-0.06 \mathrm{C}$ (LC-) and Nb-1Zr$0.1 \mathrm{C}\left(064^{-)}\right)$sheet samples.

\begin{tabular}{|c|c|c|c|c|c|c|}
\hline \multirow{2}{*}{ SAMPLE } & \multicolumn{4}{|c|}{ CHEMICAL COMPOSITION (wt.\%) } & \multirow{2}{*}{$\begin{array}{c}\text { GRAIN SIZE } \\
(\mu \mathrm{M})\end{array}$} & \multirow{2}{*}{$\begin{array}{r}\text { ASPECT } \\
\text { RATIO }\end{array}$} \\
\hline & $0^{(2)}$ & $\mathrm{N}^{(\mathbf{a})}$ & $\mathbf{C}^{(\mathrm{b})}$ & $\mathbf{Z r}^{(c)}$ & & \\
\hline LC & 0.0078 & 0.0053 & 0.0630 & 0.90 & & \\
\hline LC-DA & 0.0034 & 0.0050 & 0.0500 & 0.90 & $25 \pm 4$ & $1-3$ \\
\hline LC-DA/AGE & 0.0031 & 0.0030 & 0.0600 & 0.90 & $25 \pm 1$ & $1-2$ \\
\hline LC-DA10(E) & 0.0080 & 0.0032 & 0.0640 & 0.90 & $21 \pm 3$ & $1-2$ \\
\hline LC-DA10(M) & 0.0430 & 0.0026 & 0.0620 & 0.90 & $26 \pm 1$ & $1-2$ \\
\hline LC-DA/AGE10(E) & 0.0120 & 0.0040 & 0.0640 & 0.90 & $27 \pm 2$ & $1-2$ \\
\hline LC-DA/AGE10(M) & 0.0270 & 0.0035 & 0.0610 & 0.90 & $29 \pm 3$ & $1-2$ \\
\hline 064-INGOT & 0.0050 & 0.0025 & 0.0910 & 0.96 & & \\
\hline $064 \mathrm{~A}$ & 0.0035 & 0.0025 & 0.0900 & 0.93 & & \\
\hline 064A-DA & 0.0028 & 0.0019 & 0.0921 & 0.95 & $110 \pm 14$ & $1-2$ \\
\hline 064A-DA34(E) & 0.0133 & 0.0026 & 0.0920 & 0.95 & $31 \pm 2$ & $1-2$ \\
\hline 064A-DA34(M) & 0.0220 & 0.0044 & 0.0980 & 0.95 & $32 \pm 4$ & $1-2$ \\
\hline 064B-DA & 0.0033 & 0.0022 & 0.0914 & 0.95 & $69 \pm 7$ & $1-3$ \\
\hline 064B-DA34(E) & 0.0176 & 0.0046 & 0.0890 & 0.95 & $39 \pm 4$ & $1-2$ \\
\hline 064B-DA34(M) & 0.0217 & 0.0040 & 0.0860 & 0.95 & $42 \pm 5$ & $1-2$ \\
\hline 064C-DA & 0.0022 & 0.0009 & 0.0944 & 0.95 & $32 \pm 3$ & $1-10$ \\
\hline 064C-DA34(E) & 0.0740 & 0.0079 & 0.0920 & 0.95 & $71 \pm 10$ & $1-3$ \\
\hline 064C-DA34(M) & 0.0420 & 0.0113 & 0.0870 & 0.95 & $79 \pm 7$ & $1-3$ \\
\hline
\end{tabular}

\footnotetext{
(a) Inert gas fusion method.

(b) Combustion extraction method.

(c) Inductively-coupled plasma (ICP) method.
} 
Chemical Analysis: Table II shows that there was some decrease in the 0 -content upon double-anneal of all the samples, and this was accompanied by a decrease in $C$-content in LC-DA. These losses may have been in the form of $\mathrm{CO}$ and/or $\mathrm{CO}$ during the heat treatment. However, all the samples picked up 0 during the creep testing at $1350 \mathrm{~K}$. In general, this contamination appeared to be higher in the middle regions as compared to the ends of the crept samples. The lack of oxides in phase-extracted residue indicates that 0 was in solid solution in the samples. There was no significant change in $\mathrm{C}$ or $\mathrm{N}$ contents during the tests. Given the long testing periods, the extent of contamination can be considered minimal.

As-Received Samples: The as-cast, as-extruded and as-rolled microstructures in Fig. I were typical of the other similar samples. Fig. 1(a) shows that the coarse precipitates were distributed throughout the matrix and somewhat continuously along the grain boundaries of the cast sample. Most of these precipitates were over $10 \mu \mathrm{m}$ along their major axes. Fig. 1(b) shows that 4:1 extrusion at $1900 \mathrm{~K}$ caused the precipitates to break down, and align in the extrusion direction; however, needle-like precipitates, similar to those in the as-cast sample, were also present. The cold-rolled samples (Figs. 1(c,d)) had microstructures with highly-deformed grains and precipitates aligned in the rolling direction. The precipitates were more discrete and rounded, and varied in size from less than $1 \mu \mathrm{m}$ to over $5 \mu \mathrm{m}$. It is evident that marked changes in precipitate morphology and distribution took place during the operations used in sheet fabrication.

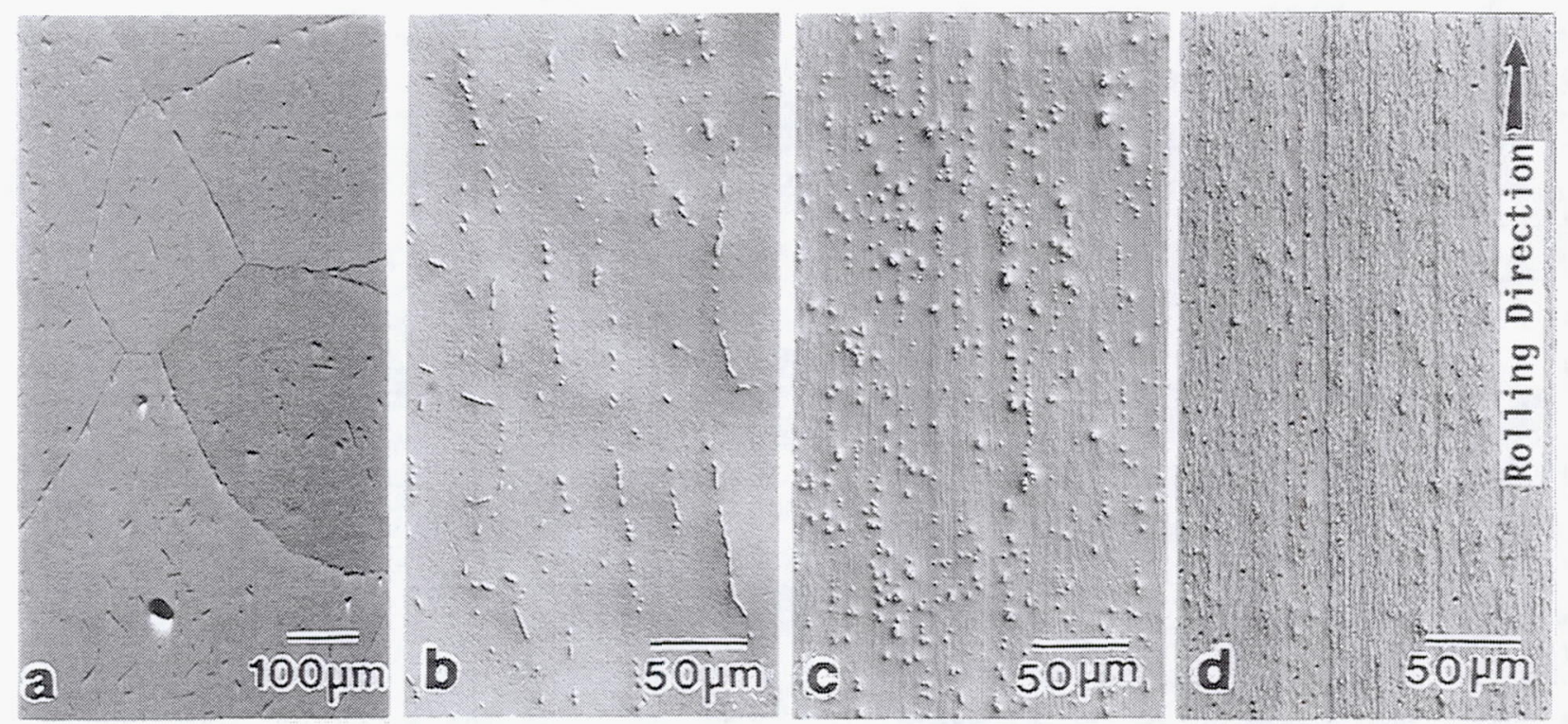

Figure 1. Microstructures of $\mathrm{Nb}-1 \mathrm{Zr}-0.1 \mathrm{C}$ alloy samples: (a) as-cast, secondaryelectron SEM image, as-etched; (b) single-extruded bar, optical, differential interference contrast (DIC), as-polished, (c) 064A: as-rolled sheet from singleextruded bar, optical, DIC, as-polished; (d) the same as (c), but also etched.

Annealed Samples: Fig. 2(a) shows the microstructure of the double-annealed Nb$1 \mathrm{Zr}-0.06 \mathrm{C}$ sample (LC-DA) which appeared recrystallized. The grains were nominally equiaxed with an aspect ratio of less than 2 and an average grain size of about $25 \mu \mathrm{m}$ (Table II). The double-annealed and aged sample (LC-DA/AGE) was very similar in appearance to Fig. 2(a) indicating ageing of LC-DA at $1350 \mathrm{~K}$ for 1000 $h$ had no significant effect on its structure. However, there were noticeable differences among the microstructures of the double-annealed samples from the single-, double- and triple-extruded $\mathrm{Nb}-1 \mathrm{Zr}-0.1 \mathrm{C}$ sheets as are evident from Figs. 2 (b-d) and Table II. Both 064A-DA and 064B-DA had relatively equiaxed grains with 


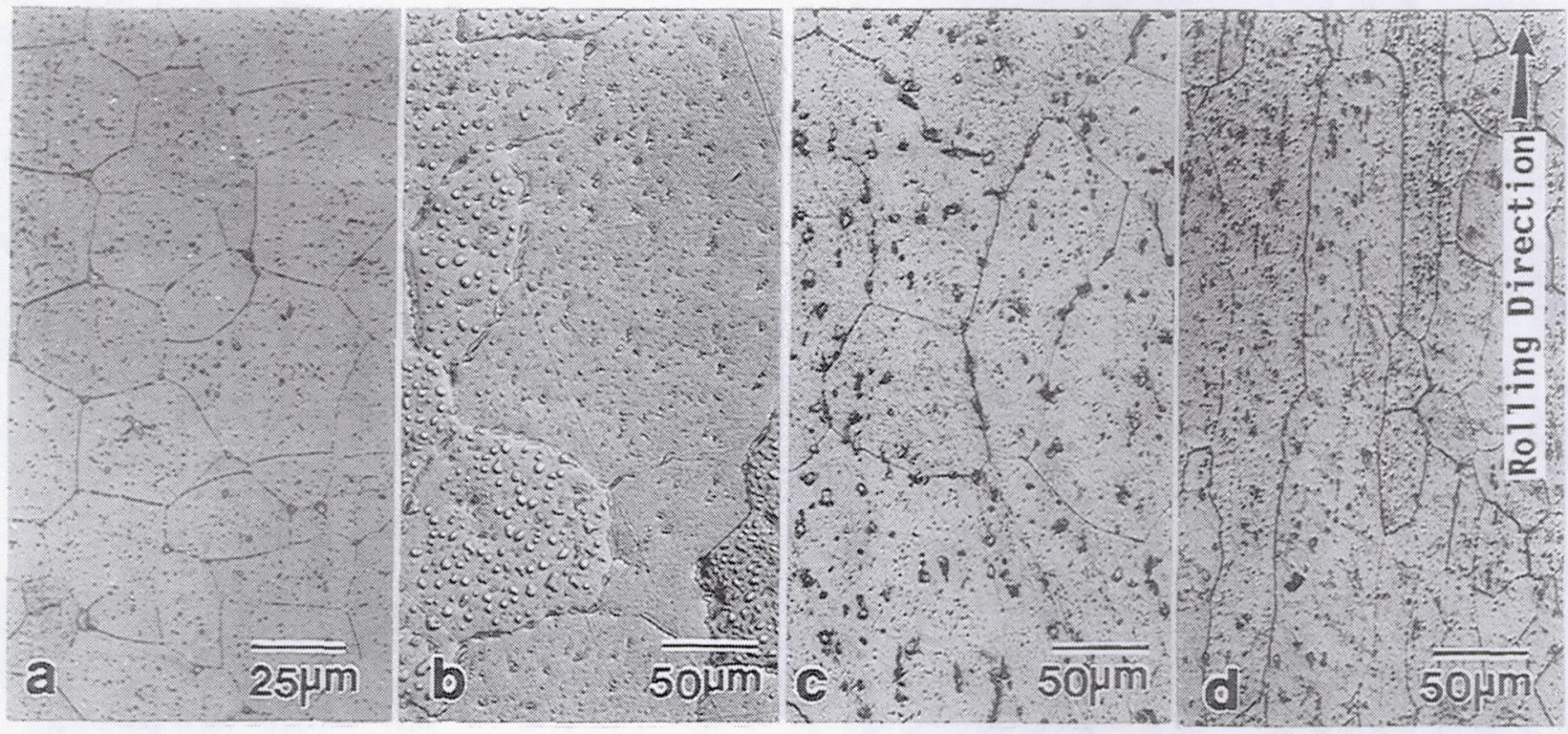

Figure 2. Double-annealed (DA: $1 \mathrm{~h} \odot 1755 \mathrm{~K}$ and $2 \mathrm{~h}$ @ $1475 \mathrm{~K}$ ) microstructures of samples from (a) $\mathrm{Nb}-1 \mathrm{Zr}-0.06 \mathrm{C}$ sheet LC-DA, (b) single-extruded $\mathrm{Nb}-1 \mathrm{Zr}-0.1 \mathrm{C}$ sheet 064A-DA, (c) double-extruded Nb-12r-0.1C sheet 064B-DA, and (d) triple-extruded sheet 064C-DA. A11 as-polished and etched, DIC.

an aspect ratio of less than 3 indicating full recystallization, but 064C-DA had mostly elongated grains with aspect ratios varying from 1 to nearly 10 . The average grain size of these samples were approximately 112, 69 and $32 \mu \mathrm{m}$ for 064A-DA, 064B-DA and 064C-DA, respectively. These observations indicate that the degree of recrystallization and average grain size decreased with increased number of extrusions. This may be due to the marked difference in the percent cold work (\%CW) in the as-rolled sheets $\mathrm{Nb}-1 \mathrm{Zr}-0.1 \mathrm{C}$ (Table I). The \%CW in $064 \mathrm{C}$ (66\%) was much smaller than that in either of the $064 \mathrm{~A}$ and $064 \mathrm{~B}$ ( 96 and $88 \%$, respectively). This would lead to lower stored energy and driving force for complete recrystallization. Another possible explanation for the highly elongated grains in 064C-DA may be that the precipitates stopped the growth in the transverse direction. However, this should have been, but was not, the case in other samples. Regardless of the apparent differences in their microstructures, the precipitates, varying in size (from 1 to about $5 \mu \mathrm{m}$ ), were finely distributed throughout the matrix and along the grain boundaries in all the samples. Also, the precipitates appeared to be more abundant in the 0.1-C samples than in the $0.06-C$ samples as expected.

Crept Samples: Fig. 3(a-d) show the microstructures of the gage sections of samples LC-DA10, 064A-DA34, 064B-DA34 and 064C-DA34. The microstructure of the gage and low-stress end sections of each sample were similar. This was not unexpected, because the total strain in each of the crept samples was negligibly small (<0.3\%). A comparison of Fig. 3(a) with Fig. 2(a) shows that the microstructure, including the grain size (Table II) of LC-DA did not change significantly during exposure at $1350 \mathrm{~K}$ for over $30,000 \mathrm{~h}$ with or without the applied stress. This was also the case for LC-DA/AGE indicating that ageing at $1350 \mathrm{~K}$ for $1000 \mathrm{~h}$ following the double-anneal did not deteriorate the excellent high-temperature stability of the microstructure of the $\mathrm{Nb}-1 \mathrm{Zr}-0.06 \mathrm{C}$ alloy.

In contrast to the $0.06-C$ sheets, changes during the creep testing of the samples from the 0.1-C sheets were more apparent as can be seen from a comparison of their respective microstructures in Figs. 2 and 3 and the grain size data in Table II. The grains of the crept samples from the single- and double-extruded 

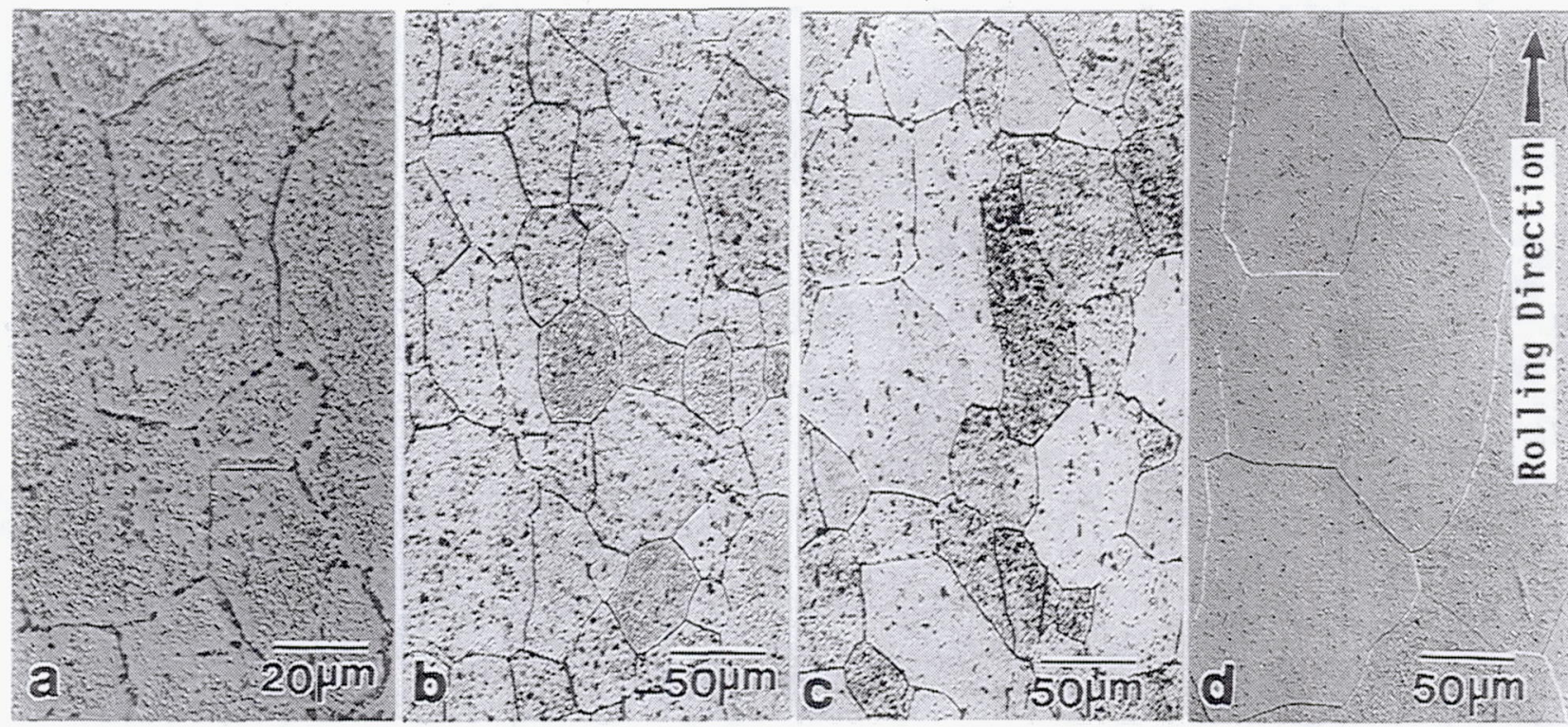

Figure 3. Microstructures of the gage sections of the samples after creep testing at $1350 \mathrm{~K}$ and (a) $10 \mathrm{MPa}$ for $34,500 \mathrm{~h}$ (LC-DA10(M)), (b) $34.5 \mathrm{MPa}$ for $18,780 \mathrm{~h}$ (064A-DA34(M)), (c) $34.5 \mathrm{MPa}$ for $15,460 \mathrm{~h}(064 \mathrm{~B}-\mathrm{DA} 34(\mathrm{M}))$, and (d) $34.5 \mathrm{MPa}$ for $9950 \mathrm{~h}(064 \mathrm{C}-\mathrm{DA} 34(\mathrm{M}))$. A11 as-polished and etched, DIC.

sheets (064A-DA34 and 064B-DA34, respectively) were still relatively equiaxed, but appeared to have undergone noticeable refinement in size. The decrease in the grain size upon exposure to $1350 \mathrm{~K}$ and $34.5 \mathrm{MPa}$ was from about 110 to $30 \mu \mathrm{m}$ for 064A-DA after nearly $19,000 \mathrm{~h}$, and from roughly 70 to $40 \mu \mathrm{m}$ for 064B-DA after about $15,500 \mathrm{~h}$. While a decrease in grain size during thermal exposure is unusual, it is possible that the low-angle boundaries were not revealed by etching in the double-annealed samples from these sheets. Subsequent long-time exposure to $1350 \mathrm{~K}$, however, could have resulted in the exposure of such boundaries as a result of solute segregation and carbide precipitation. The changes in the microstructure of $064 \mathrm{C}-\mathrm{DA}$ were more as expected upon creep testing for nearly $10,000 \mathrm{~h}$ at $1350 \mathrm{~K}$. (Figs. 2(d) and $3(\mathrm{~d}))$. The grains were highlyelongated with an average size of about $31 \mathrm{\mu m}$ prior to the test, but became fairly equiaxed with over a 2-fold increase in size (Table II). This would indicate that grain growth, especially in the transverse direction, occurred in this sample during the prolonged exposure to $1350 \mathrm{~K}$.

In order to verify that the protrusions and/or pits in the as-polished and/or etched samples were indeed precipitates rather than optical artifacts, the samples were also examined via an SEM. Representative results can be seen from Fig. 4 which shows the back-scattered electron images of samples from the singleextruded sheet before and after creep testing, (064A-DA and 064A-DA34(M), respectively). The precipitates, which are carbides of $\mathrm{Nb}$ and/or $\mathrm{Zr}$, appear darker in these images, because they have a lower average atomic number than the $\mathrm{Nb}-\mathrm{Zr}$ matrix. While the carbides varied in size, and were rather coarse and somewhat continuous along the grain boundaries of 064A-DA, they were a micrometer or less and finely-distributed throughout the matrix in 064A-DA34(M).

\section{Work on Phase-Extracted Residue}

The results of the analyses of the phase-extracted residues are tabulated in Table III. The precipitates in the as-rolled $\mathrm{Nb}-1 \mathrm{Zr}-0.06 \mathrm{C}$ (LC) sheet were orthorhombic $\mathrm{Nb}_{2} \mathrm{C}$, and the residue analyzed nearly all $\mathrm{Nb}$. In the double-annealed sample LC-DA, some cubic phase, $(\mathrm{Zr}, \mathrm{Nb}) \mathrm{C}$ was detected together with $\mathrm{Nb}_{2} \mathrm{C}$, 

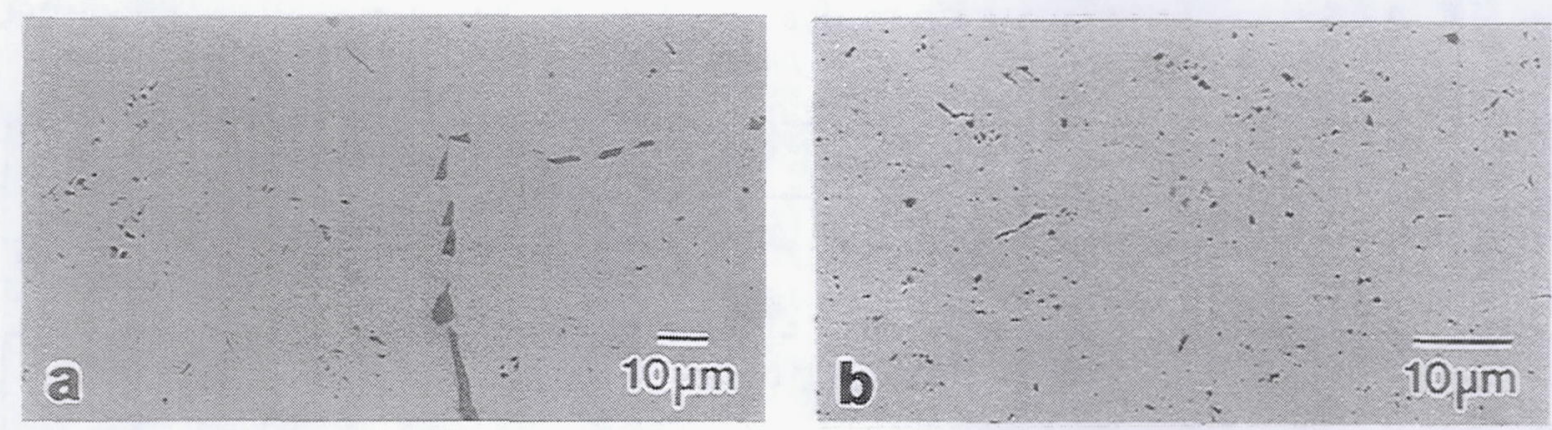

Figure 4. Back-scattered SEM images of samples from single-extruded Nb-1Zr-0.1C sheet (a) as double-annealed (064A-DA), and (b) after creep testing at $1350 \mathrm{~K}$ and $34.5 \mathrm{MPa}$ for $18,780 \mathrm{~h}(064 \mathrm{~A}-\mathrm{DA} 34(\mathrm{M}))$.

and this was accompanied with a very small increase in $\mathrm{Zr} / \mathrm{Nb}$ ratio. The only phase detected in LC-DA/AGE was the cubic carbide with a of about $0.460 \mathrm{~nm}$ indicating that ageing of the double-annealed sample at $1350 \mathrm{~K}$ for $1000 \mathrm{~h}$ resulted in conversion of all $\mathrm{Nb} C$ to $(\mathrm{Zr}, \mathrm{Nb}) \mathrm{C}$. This was also accompanied by a significant increase in $\mathrm{Zr} / \mathrm{Nb}$ ratio from $\sim 0.04$ to $\sim 0.6$. The only phase detected in the crept samples from the $\mathrm{Nb}-1 \mathrm{Zr}-0.06 \mathrm{C}$ alloy was $(\mathrm{Zr}, \mathrm{Nb}) \mathrm{C}$ with a $\mathrm{Zr} / \mathrm{Nb}$ ratio of greater than 1. This indicates that exposure to $1350 \mathrm{~K}$ for over $30,000 \mathrm{~h}$ did not change the phase make-up of LC-DA/AGE, while it resulted in complete transformation of $\mathrm{Nb}_{2} \mathrm{C}$ to $(\mathrm{Zr}, \mathrm{Nb}) \mathrm{C}$ in $\mathrm{LC}-\mathrm{DA}$, possibly during the first $1000 \mathrm{~h}$. The changes in the phase make up of $\mathrm{Nb}-1 \mathrm{Zr}-0.1 \mathrm{C}$ samples (064- in Table III) during high temperature exposure were similar to those of $\mathrm{Nb}-1 \mathrm{Zr}-0.06 \mathrm{C}$. The only type of precipitate detected in the residue of the as-cast ingot was $\mathrm{Nb}_{2} \mathrm{C}$ which again analyzed nearly all $\mathrm{Nb}$ indicating that $\mathrm{Zr}$ was in solid solution. High temperature extrusions prior to cold rolling, subsequent double-anneal heat treatment and prolonged exposure to $1350 \mathrm{~K}$ evidently resulted in increasing transformation of $\mathrm{Nb}_{2} \mathrm{C}$ to $(\mathrm{Zr}, \mathrm{Nb}) \mathrm{C}$. This is evident from the increased detection of the cubic phase and the accompanying increase in the $\mathrm{Zr} / \mathrm{Nb}$ ratio along the process path of each of the samples in Table III. Again, the only phase detected in the residue from the crept samples was the cubic $(\mathrm{Zr}, \mathrm{Nb}) \mathrm{C}$ indicating complete transformation of $\mathrm{Nb}_{3} \mathrm{C}$ to the more stable $(\mathrm{Zr}, \mathrm{Nb}) \mathrm{C}$. Another noteworthy trend observed was that the $\mathrm{Zr} / \mathrm{Nb}$ ratio, which is an indicator of the relative abundance of the cubic carbides, increased with increasing number of extrusions (Table III). This trend was reinforced by also analyzing the residue from the double-annealed $\mathrm{Nb}-1 \mathrm{Zr}-0.1 \mathrm{C}$ sheets by energy-dispersive $\mathrm{x}$-ray spectroscopy using SEM as can be seen from the last column in Table III. Furthermore, the identification of the precipitates by $x$-ray and chemical analysis of the residue has been verified by TEM studies ${ }^{23}$. In $064 A$, the precipitates were determined to be orthorhombic $\mathrm{Nb}_{3} \mathrm{C}$ regardless of size which varied from 1 to about $5 \mu \mathrm{m}$. In the double annealed samples, the coarser precipitates were again $\mathrm{Nb}_{2} \mathrm{C}$, but the finer precipitates ( $1 \mu \mathrm{m}$ or less) were cubic $(\mathrm{Zr}, \mathrm{Nb}) \mathrm{C}$. These cubic carbides were coherent with the matrix and were finely-distributed in the samples exposed to $1350 \mathrm{~K}$ for very long times.

The lattice parameters, $a_{0}$, of the cubic phase in Table III, 0.450-0.468 nm fall between the $a_{o}$ values of $N b C \quad(\approx 0.447 \mathrm{~nm})$ and $\operatorname{ZrC}(\approx 0.470 \mathrm{~nm})$. As both carbides have FCC crystal structures, it is probable that the cubic precipitates are solid solutions of $\mathrm{NbC}$ and $\mathrm{ZrC}$. As the phase transformation from $\mathrm{Nb}, \mathrm{C}$ to $(\mathrm{Zr}, \mathrm{Nb}) \mathrm{C}$ increased, the $\mathrm{Zr} / \mathrm{Nb}$ ratio in the residue of a sample also increased and was generally accompanied by an increase in the $a_{0}$ value of the cubic carbide. This would be expected, because $a_{0}(Z r)>a_{0}(N b)$ and $a_{0}(Z r C)>a_{0}(N b C)$. Similar $a_{0}$ values and $\mathrm{Zr} / \mathrm{Nb}$ ratios for $(\mathrm{Zr}, \mathrm{Nb}) \mathrm{C}$ as those in Table III have also been reported in the literature ${ }^{11,18-23}$. It has also been suggested that the solid 
Table III. Results of the analysis of phase-extracted residue from $\mathrm{Nb}-1 \mathrm{Zr}-0.06 \mathrm{C}$ (LC-) and Nb-1Zr-0.1C (064-) samples.

\begin{tabular}{|c|c|c|c|c|c|c|}
\hline \multirow{3}{*}{ SAMPLE } & \multicolumn{4}{|c|}{ X-RAY ANALYSIS } & \multicolumn{2}{|c|}{$\mathrm{Zr} / \mathrm{Nb}$ RATIO } \\
\hline & \multirow{2}{*}{ PHASES } & \multicolumn{3}{|c|}{ LATTICE PARAMETERS (nm) } & \multirow{2}{*}{$\begin{array}{c}\text { CHEM } \\
\text { ANALYSIS }\end{array}$} & \multirow{2}{*}{$\begin{array}{l}\text { SEM }^{(\Omega)} \\
\text { XEDS }\end{array}$} \\
\hline & & $\mathbf{a}_{0}$ & $\mathbf{b}_{0}$ & $\mathrm{C}_{0}$ & & \\
\hline $\begin{array}{l}\text { LC } \\
\text { LC-DA } \\
\text { LC-DA10(E) } \\
\text { LC-DA10(M) } \\
\text { LC-DA/AGE10 } \\
\text { LC-DA/AGE10(E) } \\
\text { LC-DA/AGE10(M) }\end{array}$ & $\begin{array}{c}\mathrm{Nb}_{2} \mathrm{C} \\
(\mathrm{Zr}, \mathrm{Nb}) \mathrm{C} \\
\mathrm{Nb}_{2} \mathrm{C} \\
(\mathrm{Zr}, \mathrm{Nb}) \mathrm{C} \\
(\mathrm{Zr}, \mathrm{Nb}) \mathrm{C} \\
(\mathrm{Zr}, \mathrm{Nb}) \mathrm{C} \\
(\mathrm{Zr}, \mathrm{Nb}) \mathrm{C} \\
(\mathrm{Zr}, \mathrm{Nb}) \mathrm{C} \\
(\mathrm{Zr}, \mathrm{Nb}) \mathrm{C}\end{array}$ & $\begin{array}{l}1.09 \\
0.468 \\
\\
0.458 \\
0.465 \\
0.464 \\
0.460 \\
0.465 \\
0.465\end{array}$ & 0.492 & 0.311 & $\begin{array}{l}1 / 99 \\
4 / 96 \\
72 / 27 \\
63 / 37 \\
38 / 62 \\
60 / 40 \\
56 / 44\end{array}$ & \\
\hline 064-INGOT & $\mathrm{Nb}_{2} \mathrm{C}$ & 1.092 & 0.498 & 0.310 & $2 / 98$ & \\
\hline $064 \mathrm{~A}$ & $\begin{array}{c}\mathrm{Nb}_{2} \mathrm{C} \\
(\mathrm{Zr}, \mathrm{Nb}) \mathrm{C}\end{array}$ & $\begin{array}{l}1.092 \\
0.453\end{array}$ & 0.497 & 0.311 & $3 / 97$ & \\
\hline $\begin{array}{l}\text { 064A-DA } \\
\text { 064A-DA34(E) } \\
\text { 064A-DA34(M) }\end{array}$ & $\begin{array}{c}\mathrm{Nb}_{2} \mathrm{C} \\
(\mathrm{Zr}, \mathrm{Nb}) \mathrm{C} \\
(\mathrm{Zr}, \mathrm{Nb}) \mathrm{C} \\
(\mathrm{Zr}, \mathrm{Nb}) \mathrm{C}\end{array}$ & $\begin{array}{l}1.09 \\
0.450 \\
0.454 \\
0.454\end{array}$ & 0.48 & 0.29 & $\begin{array}{l}10 / 90 \\
58 / 42 \\
54 / 46\end{array}$ & $11 / 89$ \\
\hline 064B & $\begin{array}{c}\mathrm{Nb}_{2} \mathrm{C} \\
(\mathrm{Zr}, \mathrm{Nb}) \mathrm{C}\end{array}$ & 1.09 & 0.499 & 0.311 & $14 / 96$ & \\
\hline 064B-DA & $\begin{array}{c}\mathrm{Nb}_{2} \mathrm{C} \\
(\mathrm{Zr}, \mathrm{Nb}) \mathrm{C}\end{array}$ & 0.459 & & & $37 / 63$ & $30 / 70$ \\
\hline 064B-DA34(E) & $(\mathrm{Zr}, \mathrm{Nb}) \mathrm{C}$ & 0.456 & & & $63 / 37$ & \\
\hline 064B-DA34(M) & $(\mathrm{Zr}, \mathrm{Nb}) \mathrm{C}$ & 0.454 & & & $57 / 44$ & \\
\hline $064 \mathrm{C}$ & $\begin{array}{c}\mathrm{Nb}_{2} \mathrm{C} \\
(\mathrm{Zr}, \mathrm{Nb}) \mathrm{C}\end{array}$ & 1.09 & 0.497 & 0.311 & $25 / 75$ & \\
\hline 064C-DA & $(\mathrm{Zr}, \mathrm{Nb}) \mathrm{C}$ & 0.459 & & & $63 / 37$ & $71 / 29$ \\
\hline 064C-DA34(E) & $(\mathrm{Zr}, \mathrm{Nb}) \mathrm{C}$ & 0.459 & & & $72 / 28$ & \\
\hline 064C-DA34(E) & $(\mathrm{Zr}, \mathrm{Nb}) \mathrm{C}$ & 0.458 & & & $85 / 15$ & \\
\hline
\end{tabular}

(a) Average of analysis of 4 areas ranging in size $250 \times 250 \mu \mathrm{m}$ to $5 \times 5 \mu \mathrm{m}$.

solutions of $\mathrm{NbC}$ and $\mathrm{ZrC}$ yield non-stoichiometric carbides of $(\mathrm{Zr}, \mathrm{Nb}) \mathrm{C}_{\mathrm{x}}$ or $\mathrm{Zr}_{\mathrm{x}} \mathrm{Nb}_{1}$. ${ }_{x} C_{y}$ with $x$ and $y$ varying between 0.8 and 0.98 , but this could not be verified in this study. However, it is evident from the results of this study that the finely distributed cubic carbides of $(\mathrm{Zr}, \mathrm{Nb}) \mathrm{C}$ form as a result of transformation from $\mathrm{Nb}_{2} \mathrm{C}$ during thermomechanical processing and/or exposure to elevated temperatures. This transformation has been reported to be complete from about $100 \mathrm{~h}^{19}$ to over $10,000 \mathrm{~h}^{18}$ of ageing at temperatures over $1300 \mathrm{~K}$. The results in this study show that the transformation of $\mathrm{Nb}_{2} \mathrm{C}$ to the stable monocarbide was complete within the first $1000 \mathrm{~h}$ of exposure to $1350 \mathrm{~K}$ in the $\mathrm{Nb}-1 \mathrm{Zr}-0.06 \mathrm{C}$ alloy. In the $\mathrm{Nb}-1 \mathrm{Zr}-0.1 \mathrm{C}$ sheets, it appeared to be completed during the double-anneal in the tripleextruded sheet, 064C-DA, and may have been completed in the others early during the exposure to $1350 \mathrm{~K}$ with or without applied stress. 


\section{CONCLUSIONS}

The results presented in this paper clearly show that the rather coarse $\mathrm{Nb}_{2} \mathrm{C}$, which is orthorhombic and forms during casting of $\mathrm{Nb}-1 \mathrm{Zr}-\mathrm{C}$ alloys, increasingly transforms to submicron-sized cubic $(\mathrm{Zr}, \mathrm{Nb}) \mathrm{C}$ during thermomechanical processing and/or high temperature exposure. The transformation of $\mathrm{Nb}_{2} \mathrm{C}$ to $(\mathrm{Zr}, \mathrm{Nb}) \mathrm{C}$ was essentially complete in a $\mathrm{Nb}-1 \mathrm{Zr}-0.06 \mathrm{C}$ sheet within $1000 \mathrm{~h}$ at 1350 $\mathrm{K}$ following a double-anneal heat treatment ( $1 \mathrm{~h}$ e $1755 \mathrm{~K}+2 \mathrm{~h}$ - $1475 \mathrm{~K}$ ). The phase transformation was complete also during the double-anneal in the tripleextruded sheet and during the subsequent $1350-\mathrm{K}$ exposure in the single- and double-extruded sheets from the $\mathrm{Nb}-1 \mathrm{Zr}-0.1 \mathrm{C}$ alloy. Once formed, the cubic carbides were extremely stable giving the alloy excellent microstructural stability during prolonged $(10,000-34,500 \mathrm{~h})$ exposure to $1350 \mathrm{~K}$ with or without applied stress.

Increasing the $\mathrm{C}$-content from 0.06 to 0.1 wt.\% resulted in an increase of the amount of precipitates as be expected. The multiple extrusion of $\mathrm{Nb}-1 \mathrm{Zr}-0.1 \mathrm{C}$ alloy at $1900 \mathrm{~K}$ affected the double-annealed microstructures, but appeared to have no end-benefit concerning high temperature stability. The microstructures of the samples from the single-, double - and triple-extruded sheets a 71 appeared similar with the cubic phase finely-distributed throughout the matrix.

\section{ACKNOWLEDGEMENTS}

This work was performed by the NASA Lewis Research Center for the U.S. DOE Office of Nuclear Energy and the Strategic Defense Initiative Office under interagency agreement DE-a103-86SF16310.

\section{REFERENCES}

1. R.H. Cooper, Jr., in Refractory Alloy Technology for Space Nuclear Power Applications, edited by R. H. Cooper and E. E. Hoffman, (Technical Information Center; US Department of Energy, Oak Ridge, TN 1984) pp. 14-17.

2. R. H. Titran, Advanced Materials and Processes 142(5), 34-41(1992).

3. G. C. Kruger, S. Vaidyanathan, N. Deane, R. Protsik, R.E. Murata, in SP-100 Reactor Design, (22nd Intersociety Energy Conversion Engineering Conference Proc. 1, AIAA, New York, 1989) pp. 419-423.

4. E.J. DelGrosso, C.E. Carlson and J.J. Kaminsky, JLCM 12, 173-201(1967).

5. W. Dokko, JPL Report No. JPL D-1948, Jet Propulsion Lab., Pasadena, CA, 1984.

6. A. J. Bryhan and R. C. Chan, JOM 45 (6), 50-53(1993).

7. R.H. Titran, NASA TM-100142, NASA LeRC, Cleveland, OH, 1986.

8. R.H. Titran, T.J. Moore and T.L. Grobstein, NASA TM-89834, NASA LeRC, Cleveland, $\mathrm{OH}, 1987$.

9. R.H. Titran, NASA TM-102390, NASA LeRC, Cleveland, OH, 1990.

10. Mehmet Uz and R.H. Titran, NASA TM-106319, NASA LeRC, Cleveland, OH, 1993.

11. J.T. Norton and A.L. Mowry, J. Metals 1(2), 133-136(1949). 
12. F. B. Cuff, Jr., Report ASD-TDR-62-7, PART I, Wright Patterson AFB, OH, 1962.

13. R.T. Begley, R.L. Ammon, and R.Sticker, Report WADC-TR-57-344, PART VI, Wright Patterson AFB, OH, 1963.

14. F. Ostermann and F. Bollenrath, AFML-TR-66-259, Wright Patterson AFB, 1966.

15. F. Ostermann, J. Less-Common Metals, 25, 243-256(1971).

16. A.E. Kissil, P.A. Khandarov, A.D. Rapp, L.P. Onisenko, L.Z. Polyak, A.G. Arakelov and I.I. Maximow, Sov. Mater. Sci., 12, 640-643(1976), (Eng1. Trans1.)

17. V.B. Arsomosov, and E.V. Vasi1'eva, Met. Sci. Heat Treat., 20,291-293(1978),

18. P.A. Khandarov, A.N. Luk'yanov, A.G. Arakelov, O.S. Tsvikilevich, E.M. Lyutyi and G.G. Maximovich, Sov. Mater. Sci., 14, 431-435(1978), (Engl. Trans1.)

19. A.D. Korotayev, A.N. Tyumentsev, M.G. Glazunov, L.M. Dizhar, A.I. Yakushina, S.P. Semkin and T.I. Vitkovskaya, Phys. Met. Metallogr., 52, 128-135(1981).

20. G.K. Moiseev, N.A. Vatolin and S.K. Popov, Izv. Akad. Nauk SSSR, Neorg. Mater., 19(9), 1478-1483(1983). (Eng1. Trans1.)

21. T.L. Grobstein and R.H. Titran, NASA TM-100848, NASA LeRC, Cleveland, OH, 1986.

22. Mehmet Uz and R.H. Titran, NASA TM-103647, NASA LeRC, Cleveland, OH, 1991. 23. Mehmet Uz and R.H. Titran, 10th Symp. Nuclear Power and Propulsion, AIP Conf. Proc. 271, edited by M.S. ET-Genk and M.D. Hoover, Albuquerque, NM 1993, pp. 6983.

24. ASTM Standard E112, Annual Book of ASTM Standards 03,03, ASTM, Philadelphia, $120(1984)$. 
Public reporting burden for this collection of information is estimated to average 1 hour per response, including the time for reviewing instructions, searching existing data sources, gathering and maintaining the data needed, and completing and reviewing the collection of information. Send comments regarding this burden estimate or any other aspect of this collection of information, including suggestions for reducing this burden, to Washington Headquarters Services, Directorate for Information Operations and Reports, 1215 Jefferson Davis Highway. Suite 1204. Arlington, VA 22202-4302, and to the Office of Management and Budget, Paperwork Reduction Project (0704-0188), Washington, DC 20503.

1. AGENCY USE ONLY (Leave blank)

\section{REPORT DATE}

3. REPORT TYPE AND DATES COVERED

October 1993

Technical Memorandum

\section{TITLE AND SUBTITLE}

Effects of Processing and Prolonged High Temperature Exposure on the Microstructure of $\mathrm{Nb}-1 \mathrm{Zr}-\mathrm{C}$ Sheet

6. $A U T H O R(S)$

Mehmet Uz and R.H. Titran

\section{FUNDING NUMBERS}

$$
\text { WU-583-02-21 }
$$

8. PERFORMING ORGANIZATION REPORT NUMBER

National Aeronautics and Space Administration

Lewis Research Center

Cleveland, Ohio 44135-3191
E-8176

10. SPONSORING/MONITORING AGENCY REPORT NUMBER

NASA TM-106370

DOE/NASA/16310-20

\section{SUPPLEMENTARY NOTES}

Prepared for MRS 1993 Fall Meeting sponsored by the Materials Research Society, Boston, Massachusetts, November 29-December 3, 1993. Mehmet Uz, Lafayette College, Department of Chemical Engineering, Lafayette College, Easton, Pennsylvania 18042; and R.H. Titran, Lewis Research Center. Prepared under Interagency Agreement DE-AI03-86SF16310.

12a. DISTRIBUTION/AVAILABILITY STATEMENT

Unclassified -Unlimited

Subject Category 26 12b. DISTRIBUTION CODE

DOE Category UC-25

\section{ABSTRACT (Maximum 200 words)}

High temperature stability of the microstructure of $\mathrm{Nb}-1 \mathrm{Zr}$ sheet containing 0.1 and $0.06 \mathrm{wt} . \% \mathrm{C}$ was studied as affected by processing and prolonged $1350-\mathrm{K}$ exposure with and without applied stress. Sheets were fabricated by cold rolling bars that were single-, double- or triple-extruded at $1900 \mathrm{~K}$. Creep samples were double-annealed $(1 \mathrm{~h} @ 1755 \mathrm{~K}+2 \mathrm{~h}$ @ $1475 \mathrm{~K}$ ) prior to testing at $1350 \mathrm{~K}$ and $10,000-34,500 \mathrm{~h}$. The microstructures of the as-cast, extruded, rolled, DA and crept samples were characterized using various metallographic and analytical methods. The precipitates were rather coarse $\mathrm{Nb}_{2} \mathrm{C}$ initially, but transformed to finer $(\leq 1 \mu \mathrm{m})$ carbides of $(\mathrm{Zr}, \mathrm{Nb}) \mathrm{C}$ with each subsequent high temperature process. The grain size, and the relative amount and morphology of $(\mathrm{Zr}, \mathrm{Nb}) \mathrm{C}$ were found to be affected by the number of extrusions and to some extent by C-content. However, the microstructures of all the crept samples were similar with $(\mathrm{Zr}, \mathrm{Nb}) \mathrm{C}$ distributed throughout the matrix indicating that prolonged exposure to $1350 \mathrm{~K}$ gave rise to complete transformation of $\mathrm{Nb}_{2} \mathrm{C}$ to $(\mathrm{Zr}, \mathrm{Nb}) \mathrm{C}$ regardless of the processing history. These and other observations are presented with the emphasis on the correlation between processing, microstructure and creep properties.

14. SUBJECT TERMS

Niobium alloy; Precipitates; Creep; Carbides; Microstructures; PWC-11

17. SECURTYY CLASSIFICATION OF REPORT

Unclassified
18. SECURITY CLASSIFICATION OF THIS PAGE

Unclassified
19. SECURITY CLASSIFICATION OF ABSTRACT

Unclassified 